\title{
Effects of Levamisole on Phagocytic Activity of Rainbow Trout (Oncorhynchus mykiss W.)
}

\author{
U. ISPIR, M. E. YONAR \\ Firat University, Fisheries Faculty, Department of Fish Diseases, Elazig, Turkey \\ Received October 4, 2006 \\ Accepted June 5, 2007
}

\begin{abstract}
Ispir U., M.E. Yonar: Effects of Levamisole on Phagocytic Activity of Rainbow Trout (Oncorhynchus mykiss W.). Acta Vet. Brno 2007, 76: 493-497.

In this study, activation of phagocytic cells was examined in rainbow trout (Oncorhynchus mykiss, W.) exposed to 1,5 and $10 \mu \mathrm{g} \cdot \mathrm{ml}^{-1}$ concentrations of levamisole solution. For this purpose, blood samples were taken from fish on days 1, 7 and 14 of exposure. Potential killing activity was determined by measuring oxidative radical production and phagocytic activity of neutrophils and superoxide anion production of phagocytic cells against $Y$. ruckeri. The activity of phagocytic cells in fish exposed to each of three concentrations was found higher than that in controls and the differences were statistically significant $(p<0.05, p<0.01)$. Although no activation in oxidative radical production, phagocytes and bactericidal killing activity in fish exposed to 5 and $10 \mu \mathrm{g} \cdot \mathrm{ml}^{-1}$ concentrations of levamisole solution was determined on day 7, it was observed that all indicators increased on day 14 of exposure. The present results suggest that the application of levamisole in fish farms could increase non-specific immunity and resistance to infection of fish and offer economics benefits.
\end{abstract}

Immersion, immunization, levamisole, phagocytes, superoxide anion and Yersinia ruckeri, oxidative radical production

Non-specific mechanisms are important in the defence of all multicellular animal against invading pathogenetic microorganisms. Mononuclear phagocytes or macrophages play a central role in the cellular part on the non-specific defence (Dalmo and Seljelid 1995). Leucocytes in addition to ingesting microbes, suddenly consume more oxygen from the surrounding tissues, and produce a wide range of reactive oxygen species (ROS) are involved in bactericidal activity (Sharp and Secombes 1996; Ispir and Dorucu 2005; Bashera-John et al. 2002). This phenomenon is known as the respiratory burst (Babior 1978). Following the respiratory burst or metabolic activation reaction, the consumed oxygen is converted into or reduced to superoxide anion or hydrogen peroxide with the help of unique enzymes present in the cell wall of leucocytes that are extremely bactericidal (Bashera-John et al. 2002).

Immunostimulants are important to health as they provide the building block of defence mechanisms and protection against diseases. Several promising adjuvants, natural and synthetic drugs and biological modifiers have been tested in fish in vivo and in vitro. The substances, such as chitosan, $\beta$-glucan, muramyl dipeptide, trace mineral and vitamin combinations as well as various products derived from plants and animals, are effective in stimulating or modulating non-specific defence mechanism, and offer protection against viral and bacterial diseases in fish (Siwicki et al. 1994; Siwicki et al. 2001; Kodama et al. 1993; Mulero et al. 1998a; Cuesta et al. 2002a).

Levamisole has been extensively used in both human and veterinary medicine as an anthelminthic agent (Jansenn 1976). This agent is able to enhance the response of mammalian T-lymphocytes and macrophages (Renoux 1980). Effects of levamisole on immune system of Cyprinus carpio, Oncorhynchus mykiss, Oncorhynchus kisutch and

Address for correspondence:

Unal ISPIR

Firat University, Fisheries Faculty

Department of Fish Diseases

Fax: +904242386287

23119 Elazig, Turkiye 
Sparus aurata have also been determined by in vivo studies (Anderson and Jeney 1992; Baba et al. 1993; Findlay and Mundlay 2000; Ispir and Dorucu 2005; Mulero et al. 1998b; Siwicki 1987; 1989). Although levamisole is a registered and accepted drug in the European Community and by the United States' Food and Drug Administration, its metabolism is not well known. Toxicity and tissue residues have been reported after its use in some animals but not in fish (Cuesta et al. 2002b).

The purpose of this study was to determine the influence of levamisole bath upon nonspecific cell-mediated immunity and on phagocytic activity against Yersinia ruckeri in the intensive culture of rainbow trout (Oncorhynchus mykiss).

\section{Materials and Methods}

Healthy rainbow trout weighing between 42.0 - $87.3 \mathrm{~g}$, were obtained from local fish farming, Elazig, Turkey. The fish were kept in tanks with 4001 capacity, with water recirculation. The water was maintained $15 \pm 1{ }^{\circ} \mathrm{C}$ and $\mathrm{pH}: 7.4 \pm 0.1$ and dissolved $\mathrm{O}_{2} 9.4 \pm 0.7 \mathrm{mg} \cdot \mathrm{ml}^{-1}$. The fish were fed twice daily, 7 days a week. The fish were divided into 4 groups, with 30 fish in each group. After a 2-week acclimation period, the experimental groups were exposed to a $1-\mathrm{h}$ bath in 1,5 and $10 \mu \mathrm{g} \cdot \mathrm{ml}^{-1}$ levamisole and the control group in phosphate buffered saline (PBS, $\mathrm{pH}$ : 7.2). Blood was taken from the caudal vessels of anaesthetised (Benzocaine, $50 \mathrm{mg} \cdot \mathrm{ml}^{-1}$ ) fish to determine Nitroblue tetrazolium (NBT) activites, phagocyctic activity and potential killing activities of neutrophils and monocytes on days 1, 7 and 14 post treatment by using the methods in Siwicki and Anderson (1993) and Siwicki et al. (1994).

For the detection of NBT activity by spectrophotometric assay, $0.1 \mathrm{ml}$ of blood was placed into a microtitre plate well, and then an equal amount of $0.2 \%$ NBT solution was added. After incubation at room temperature for $30 \mathrm{~min}, 0.05 \mathrm{ml}$ of NBT-blood cell suspension was removed and added to a glass tube containing $1.0 \mathrm{ml}$ of $\mathrm{N}, \mathrm{N}$ dimethyl formamide. After centrifugation, reading in a spectrophometer at $620 \mathrm{~nm}$ in a $1.0 \mathrm{ml}$ cuvette was performed.

The heparinized blood was immediately used for the phagocyctic assay. Briefly, $1 \times 10^{8}$ cells $/ \mathrm{ml}$ of Staphylococcus sp. in $0.1 \mathrm{ml}$ of PBS were added to $0.1 \mathrm{ml}$ of blood samples in a microplate and incubation for 30 min after thorough mixing in well. After incubation, the plate was mixed gently and $0.05 \mathrm{ml}$ of this suspension was smeared on the glass side. After air drying, the smears were fixed in ethanol, and cells and phagocytised bacteria were counted.

For the detection of intracellular superoxide radical production, $0.1 \mathrm{ml}$ of blood solution was mixed with and equal volume $0.2 \%$ NBT solutions in PBS containing $0.1 \mathrm{ml}$ of EMEM-0.1 (Eagle's Minimal Essential Media with $0.1 \%$ foetal calf serum) in microtitre plates in duplicate. After incubation at room temperature for $60 \mathrm{~min}$, the mixture was mixed with NBT solution containing $1 \times 10^{8}$ Yersinia ruckeri cells $/ \mathrm{ml}$. The plates were shaken for $5 \mathrm{~min}$ and supernatants discharged. Cells were then washed twice in $70 \%$ methanol. After the final washing, the methanol was removed. The optical density (OD) of the samples was read at $620 \mathrm{~nm}$ against a Potasium hydroxide/Dimethyl sulfoxide (KOH/DMSO) blank in a spectrophotometer.

Differences in immunological indicators between experimental and control fish were analysed by Student's $t$ - test using Minitab Statistical Software Release 10.

\section{Results}

Values of indicators of non-specific defense system in the control group and levamisolebath fish groups are given in Figs. 1 - 3.

After one day the administration of levamisole, oxidative radical production of neutrophils increased in 1,5 and $10 \mu \mathrm{g} \cdot \mathrm{ml}^{-1}$ levamisole-treated fish (Fig. 1), but after 7 days only fish bath with $1 \mu \mathrm{g} \cdot \mathrm{ml}^{-1}$ levamisole showed a significantly higher leukocyte respiratory burst activity $(p<0.05)$. However, there was an increase observed in all fish groups after 14 days.

The exposure to levamisole bath resulted in enhanced phagocytic activity of blood leukocytes (Fig. 2.); 14 days after the last administration of levamisole the percentage of blood phagocytic cells increased in all three levamisole-treated groups and the highest stimulation was observed in $10 \mu \mathrm{g} \cdot \mathrm{ml}^{-1}$ levamisole-bath treated fish. After 1- and 7-day administration of levamisole against Yersinia ruckeri no increase in potential killing activities of neutrophils and monocytes was found, but 14 days after the last administration of levamisole bath it was higher in all groups $(p<0.01)$ as compared with controls (Fig. 3). 


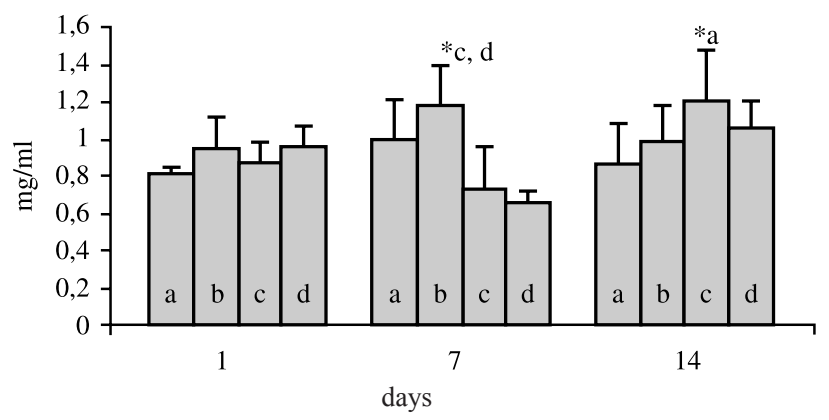

Fig. 1. Oxidative radical production in rainbow trout after levamisole administration ${ }^{*} p<0,05$ a - control, $\mathrm{b}-1 \mu \mathrm{g} \cdot \mathrm{ml}^{-1}$ levamisole, $\mathrm{c}-5 \mu \mathrm{g} \cdot \mathrm{ml}^{-1}$ levamisole, $10 \mu \mathrm{g} \cdot \mathrm{ml}^{-1}$ levamisole

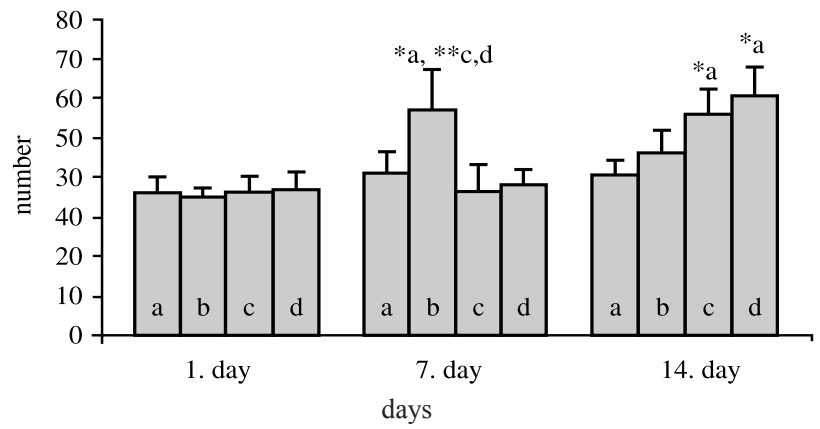

Fig. 2. The phagocytic activity of blood leukocytes isolated from rainbow trout bathed with levamisole ${ }^{*} p<0.05{ }^{* *} p<0,01$ a - control, $\mathrm{b}-1 \mu \mathrm{g} \cdot \mathrm{ml}^{-1}$ levamisole, $\mathrm{c}-5 \mu \mathrm{g} \cdot \mathrm{ml}^{-1}$ levamisole, $10 \mu \mathrm{g} \cdot \mathrm{ml}^{-1}$ levamisole

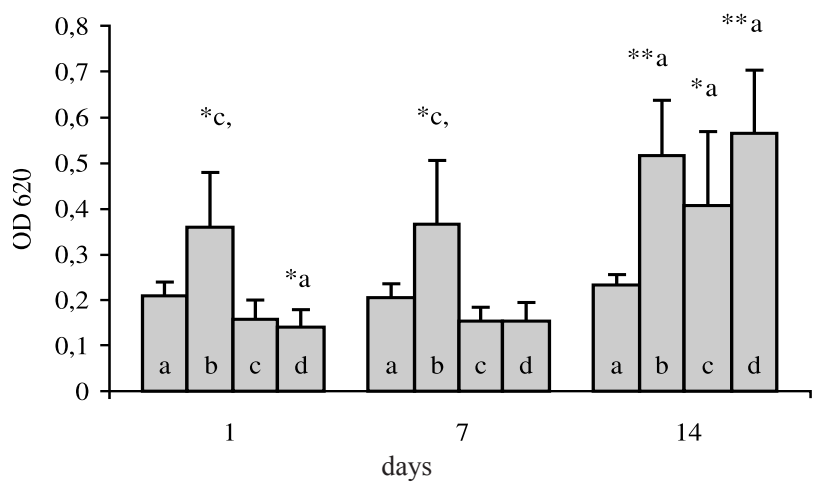

Fig. 3. Potential killing activities of neutrophils and monocytes isolated from rainbow trout bathed with levamisole

${ }^{*} p<0.05{ }^{* *} p<0.01$ a - control, $\mathrm{b}-1 \mu \mathrm{g} \cdot \mathrm{ml}^{-1}$ levamisole, $\mathrm{c}-5 \mu \mathrm{g} \cdot \mathrm{ml}^{-1}$ levamisole, $10 \mu \mathrm{g} \cdot \mathrm{ml}^{-1}$ levamisole

\section{Discussion}

A variety of immunomodulatory effects of levamisole have been established in higher vertebrates. Among the most widespread effects seems to be the enhancement of phagocytosis by polymorphonuclear cells and macrophages (Symones and Rosenthal 
1977), and augmentation of antibody response following immunisation (Tempero et al. 1995). Previous studies have shown the immunostimulatory effects of levamisole on a number of fish species (Siwicki 1987, 1989; Kajita et al. 1990; Mulero et al. 1998bc; Findlay and Mundlay 2000; Ispir and Dorucu 2005). After treatment with levamisole, both fish species showed enhanced non-specific immune activities and resistance to an experimental challenge with pathogenic bacteria. The use of levamisole with vaccines to increase the efficacy of the immune response against pathogens has also been studied (Anderson and Jeney 1992; Jeney and Anderson 1993). In this study, the effects of levamisole, bathed, on the non-specific defense mechanisms of rainbow trout were determined.

After immunization, in order to measure leukocyte activation in fish the NBTspectrophotometric method is still widely used (Stites 1994). In fact, the leukocyte population provides an important clue about the immune system of fish.

According to the results obtained from the NBT spectrophotometer test in this study oxidative radical production increased at the end of the experiment. Previous studies have also shown an increase in oxidative radical production in immunostimulated rainbow trout with the NBT test (Siwicki et al. 1994; Ispir and Dorucu 2005).

Granulocytes, mononuclear phagocytes or macrophages have an important role in nonspecific defence in fish (Dalmo et al. 1997). In the present study, phagocytised peripheral blood leukocyte potential and killing activity of neutrophils and monocytes increased in levamisole-bathed fish. Similar findings have also been reported by Anderson and Jeney (1992), Kajita et al. (1992), Sakai et al. (1992), Sakai et al. (1993), Siwicki et al. (1994), and Ispir and Dorucu (2005).

In this study we have shown stimulating effects of levamisole in all assays. There was only a considerable increase in all indicators under study in resistance 7 days after the $1 \mathrm{mg} \cdot \mathrm{ml}^{-1}$ levamisole bath $(p<0.05, p<0.01)$. However, oxidative radical production and phagocytic activity increased in all experimental groups at the end of the experiment $(p<0.05)$. Potential killing activity of neutrophil and monocytes against Yersinia ruckeri showed similar results. Potential killing activity increased immediately after the last administration of levamisole, although such activity was similar in all the groups at the end of the experiment $(p<0.05)$. In conclusion, these findings suggest that levamisole can be incorporated with bath administration in order to increase immune functions and protection in the rainbow trout. Thus, levamisole could be used to prevent mortalities caused by pathogens in fisheries.

\section{Účinek levamizolu na fagocytózu u pstruha duhového (Oncorhynchus mykiss, W.)}

$\mathrm{V}$ této studii byla u pstruha duhového (Oncorhynchus mykiss, W.) zkoumána aktivace fagocytujících buněk po aplikaci roztoku levamizolu v koncentraci $1,5 \mathrm{a} 10 \mu \mathrm{g} \cdot \mathrm{ml}^{-1}$. Za tímto účelem byly 1.,7. a 14. den po aplikaci od zviŕat odebrány vzorky krve. Potenciální cytotoxická aktivita byla určována měřením produkce oxidativních radikálů, fagocytickou aktivitou neutrofilů a produkcí superoxidového aniontu fagocytujícími buňkami proti $Y$. ruckeri. Byla zjištěna vyšší aktivita fagocytujících buněk u ryb vystavených třem různým koncentracím oproti rybám kontrolním, přičemž tyto rozdíly byly statisticky významné $(p<0.05, p<0.01)$. Ačkoliv u ryb vystavených koncentracím levamizolu 5 a $10 \mu \mathrm{g} \cdot \mathrm{ml}^{-1}$ nebyla 7 . den po expozici zjištěna aktivace produkce oxidativních radikálů, fagocytární ani baktericidní cytotoxická aktivita, 14 . den po aplikaci byly již všechny indikátory zvýšené.

\section{References}

ANDERSON DP, JENEY G 1992: Immunostimulants added to injected Aeromonas salmonicida bacterin enhance the defense mechanisms and protection in rainbow trout (Oncorhynchus mykiss). Vet Immunol Immunopathol 34:379-389 
BABA T, WATASE Y, YOSHINAGA Y 1993: Activation of mononuclear phagocyte function by levamisole immersion in Carp. Nippon Suisan Gakk 59: 301-307

BABIOR BM 1978: Oxygen-dependent microbial killing by phagocytes. New Engl J Med 298: 659-668

BASHEERA JOHN M, CHANDRAN MR, ARUNA BV, ANBARASU K 2002: Production of superoxide anion by head-kidney leucocytes of Indian major carps immunised with bacterins of Aeromonas hydrophila. Fish Shellfish Immunol 12: 201-207

CUESTA A, ESTEBAN MA, MESEGUER J 2002a: Natural cytotoxic activity in seabream (Sparus aurata L.) and its modulation by Vitamin C. Fish Shellfish Immunol 13: 97-109

CUESTAA, ESTEBAN MA, MESEGUER J 2002b: Levamisole is a potent enhancer of gilthead seabream natural cytotoxic activity. Vet Immunol Immunopathol 89: 169-174

DALMO RA, SELJELID R 1995: The immunomodulatory effect of LPS, laminaran and sulphated laminaran [ $\beta$ $(1,3)$ - D - glucan] on Atlantic salmon, Salmo salar L., macrophages in vitro. J Fish Dis 18: 175-185

DALMO RA, INGEBRIGTSEN K, BQGWALD J 1997: Non-specific defence mechanisms in fish, with particular reference to the reticuloendothelial system (RES). J Fish Dis 20: 241-273

FINDLAY VL, MUNDAY BL 2000: Immunomodulatory effects of levamisole on the nonspecific immune system of Atlantic salmon, Salmo salar L. J Fish Dis 23: 369-378

ISPIR U, DORUCU M 2005: A study on the effects of levamisole of immune system Rainbow trout (Oncorhynchus mykiss, Walbaum). Turk J Vet Anim Sci 29: 1169-1176

JANSSEN PA 1976: The levamisole story. Prog Drug Res 20: 347-383

JENEY G, ANDERSON DP 1993: An in vitro technique for surveying immunostimulants in fish. Aquaculture 112: $283-287$

KAJITA Y, SAKAI, M, ATSUTA SM 1992: Immunopotentiation activitiy of Freund's Complete Adjuvant in rainbow trout, Oncorhynchus mykiss. Nippon Suisan Gakk 58: 433-437

KAJITA Y, SAKAI M, ATSUTA S, KOBAYASHI M 1990: The immunomodulatory effects of levamisole on rainbow trout, Oncorhynchus mykiss. Fish Pathol 25: 93-98

KODAMA H, HIROTA Y, BABA T, AZUMA I 1993: Activation of rainbow trout (Oncorhynchus mykiss) phagocytes by Muramyl dipeptide. Dev Comp Immunol 17: 127-140

MULERO V, ESTABAN MA, MESEGUER J 1998a: Effects of in vitro addition of exogenous vitamins C and E on gilthead seabream (Sparus aurata L.) phagocytes. Fish Physiol Biochem 18: 399-407

MULERO V, ESTABAN MA, MUNOZ J, MESEGUER J 1998b: Dietary intake of levamisole enhances the immune response and disease resistance of the marine teleost gilthead seabream (Sparus aurata L.). Fish Shellfish Immunol 8: 49-62

MULERO V, ESTABAN MA, MESEGUER J 1998c: In vitro levamisole fails to increase seabream (Sparus aurata L.) phagocyte functions. Fish Shellfish Immunol 8: $315-318$

RENOUX G 1980: The general immunopharmacology of levamisole. Drugs 19: 89-99

SAKAI M, KAMIYA H, ATSUTA S, ISHII S, KOBAYASHI M 1992: The immunostimulating effects of chitin in rainbow trout, Oncorhynchus mykiss. In: SHARIFF M, SUBAINGHE RP, ARTHUR JR (Eds.) Diseases in Asian Aquaculture I. Asian Fisheries Society, Manila, Philippines, pp. 413-417.

SAKAI M, OTUBO T, ATSUTA S, KOBAYASHI, M 1993: Enhancement of resistance to bacterial infection in rainbow trout, Oncorhynchus mykiss, by oral administration of bovine lactoferrin. J Fish Dis 16: 239-247

SHARP G, SECOMBES CJ 1996: The role of reactive oxygenspecies in the killing of the bacterial fish pathogen Aeromonas salmonicida by rainbow trout macrophages. Fish Shellfish Immunol 3: 119-129

SIWICKI AK, MORAND M, FULLER FC, NISSEN S, KAZUN K, GLOMBSKI E 2001: Influence of HMB ( $\beta$-hydroxy- $\beta$ - methylbutyrate) on antibody secreting cells (ASC) after in vitro and in vivo immunization with the anti-Yersinia ruckeri vaccine of rainbow trout (Oncorhynchus mykiss). Vet Res 32: 491-498

SIWICKI AK 1987: Immunomodulating activity of levamisole in carp spawners, Cyprinus carpio L. J Fish Biol 31: $245-246$

SIWICKI AK 1989: Immunostimulating influence of levamisole on non-specific immunity in carp, Cyprinus carpio L. Dev Comp Immunol 13: 87-91

SIWICKI AK, ANDERSON DP 1993: Immunostimulation in fish: measuring the effects of stimulants by serological and immunological methods. Abstract Symposium on Fish Immunology, Lysekil, Sweden.

SIWICKI AK, ANDERSON DP, RUMSEY GL 1994: Dietary intake of immunostimulants by rainbow trout effects non-specific immunity and protection against furuncluosis. Vet Immunol Immunopathol 41: 125-139

STITES DP 1994: Clinical Laboratory Methods for Detection of Cellular Immunity. In: STITES DP, TERR AI, PARSLOW TG (Eds.): Basic and Clinical Immunology. Lange Med. Pub. Eighth edition. Stemford, pp. 195-212.

SYMOENS J, ROSENTHAL M 1977: Levamisole in the modulation of the immune response: the current experimental and clinical state. J Reticuloend Soc 21: 175-221

TEMPERO MA, HAGA Y, SIVINSK C, BIRT D, KLASSEN L, THIELE G 1995: Immunologic effects of levamisole in mice and humans: evidence for augmented antibody response without modulation of cellular cytotoxicity. J Immunother 17: 47-57 